\title{
STUDY OF THE GAUSSIAN DISTRIBUTION HEAT SOURCE MODEL APPLIED TO NUMERICAL THERMAL SIMULATIONS OF TIG WELDING PROCESSES
}

\author{
ESTUDO DO MODELO DE FONTE DE CALOR DE DISTRIBUIÇÃO GAUSSIANA NA APLICAÇÃO DE \\ SIMULAÇÕES TÉRMICAS NUMÉRICAS DOS PROCESSOS DE SOLDAGEM TIG
}

\author{
Paulo Roberto de Freitas Teixeira ${ }^{1}$, Douglas Bezerra de Araújo ${ }^{2}$, Luiz Antônio Bragança da Cunha ${ }^{3}$ \\ Universidade Federal do Rio Grande - FURG, Escola de Engenharia \\ ${ }^{1}$ E-mail: prfreitasteixeira@gmail.com \\ ${ }^{2}$ E-mail: daraujo@furg.br \\ ${ }^{3}$ E-mail: luizcunda@furg.br
}

\begin{abstract}
Welding processes are considered a thermal-mechanical-metallurgical coupled issue. The most important boundary condition in the numerical thermal analysis is the heat source model. Although many studies have been carried out to propose different types of heat source models, the limitations of each model application have not been clearly specified. The Gaussian heat source is a model in which heat is generated over a surface; therefore, it may not be suitable to be applied to thick plates. In this study, the accuracy of the Gaussian heat source model is investigated in bead-on-plate welding by the TIG process. Analyses are performed by the ANSYS ${ }^{\circledR}$ software, considering the convection and the radiation phenomena. Several cases with different parameters of heat distribution, heat input and plate thickness have had their weld pool geometries analysed and compared with those obtained experimentally. Analyses of the influence of the radial distance from the center of the Gaussian heat source and the thickness of the plate on the bead width and the penetrated depth of the fusion zone boundary are presented. Results have shown the adequacy and the limitations of the Gaussian heat source model in the welding simulation.
\end{abstract}

Keywords: welding process, numerical simulation, heat source model, ANSYS ${ }^{\circledR}$ software.

\section{RESUMO}

Os processos de soldagem são considerados problemas termo-mecânico-metalúrgicos acoplados. A condição de contorno mais importante na análise térmica numérica é o modelo de fonte de calor. Embora muitos estudos tenham sido realizados com o objetivo de propor diferentes tipos de modelos de fontes de calor, a limitação da aplicação de cada modelo não é claramente conhecida. A fonte de calor Gaussiana é um modelo no qual o calor é gerado sobre uma superfície; por esta razão, ela não é adequada para aplicações em chapas espessas. Neste estudo, é investigada a acurácia do modelo de fonte de calor Gaussiana em uma soldagem do tipo cordão sobre chapa pelo uso do processo TIG. As análises foram realizadas por meio do programa computacional ANSYS ${ }^{\circledR}$, considerando os fenômenos de convecção e de radiação. Para diversos casos com diferentes parâmetros de distribuição de calor, intensidades de fluxos de calor e espessuras de chapa, são analisadas as geometrias transversais do cordão de solda e estas são comparadas com aquelas obtidas experimentalmente. São apresentadas as análises das influências da distância radial do centro da fonte de calor Gaussiana e das espessuras das chapas na largura e na penetração do cordão de solda. Os resultados mostram a aplicabilidade e as limitações do modelo de fonte de calor Gaussiana na simulação da soldagem.

Palavras-chave: processo de soldagem, simulação numérica, modelo de fonte de calor, programa computacional ANSYS ${ }^{\circledR}$.

\section{1 - INTRODUCTION}

The application of the numerical simulation to the welding process has recently grown mainly due to the increase in the capacity of computers and the availability of commercial numerical codes. The Finite Element Method (FEM) has been the most common technique for the analysis of welding problems which involve thermal, metallurgical and mechanical phenomena simultaneously. Lindgren (2001) and Dong (2005) have shown that thermal-mechanical decoupled analysis provides accurate results and simplifies the numerical solution. Similarly, other authors, such as Coret and Combescure (2002), Wu et al. (2009) and El-Ahmar (2007) have considered that the influence of the mechanical model on thermal and metallurgical simulations is not significant in the welding process application. However, coupling between thermal and metallurgical analyses is employed to determine temperature and phase fraction fields.

The first studies of numerical simulation of phenomena that occur in welding process were carried out by Friedman (1975) who developed a thermal-mechanical model based on FEM to calculate temperature, stress and distortion distributions. Computational programs based on FEM which take into account the elasto-plastic behavior of the material were developed by Muraki, Bryan, Masubuchi (1975) to monitor the thermal stress and the metal movement. Afterwards, Papazoglou and Masubuchi (1982) have described a technique to analyse temperature, thermal stress and residual stress distributions by FEM, including phase transformations. The authors have emphasized the importance of the phase transformation, mainly for tempered and annealing steel welding. Mochizuki et al. (2005) have recently investigated the relation between the 
residual stress and the phase transformation by employing the SYSWELD ${ }^{\circledR}$ computational program. This program includes the following characteristics: moving heat source, material deposition, metallurgical transformations, material properties that depend on the temperature and plasticity. The authors observed that thermal and residual stresses are highly sensitive to the cooling rate effects and the phase transformations.

Free and Goff (1989) had good results when using mechanical and thermal formulations to forecast residual stresses in multipass welding processes by FEM, assuming the transversal section as the computational domain and the perfect plasticity of the material. Josefson (1993) estimated the residual stresses in multipass welding cases by SOLVIA $^{\circledR}$ and ABAQUS ${ }^{\circledR}$ computational programs, which are commercial codes available to carry out non-linear analyzes by FEM. Brickstad and Josefson (1998) simulated residual stresses due to welding by ABAQUS ${ }^{\circledR}$, considering thermal and mechanical fields. They employed the element birth technique to represent the welding bead setting and to avoid some incompatibility of displacement or deformation at nodes that connect welding elements to base material ones. Fanous, Younan, Wifi (2002) have employed another technique to consider the metal deposition using moving elements and have taken into account the influence of temperature on material properties.

The main difficulty of the thermal field simulation in a welding process is the heat source modeling. Since Rosenthal (1941) proposed the analytical solution considering a punctual or a line heat source, several more realistic heat source distributions have been developed. Eagar and Tsai (1983), Cho and Kim (2002), Deng, Murakawa, Liang (2007) and Rayamyaki, Karkhin, Khomich (2007) developed and applied a surface heat source model based on the Gaussian distribution. Other researchers, such as Balasubramanian et al. (2008), Zaeh and Schober (2008) and Ziolkowski and Brauer (2009), proposed the combination of Gaussian distribution on the surface and distribution along the thickness in order to consider 3D distribution, by applying the conical Gaussian heat source model. Another proposal that uses the same combination, i.e., the Gaussian distribution with the distribution along the thickness, by applying a cylindrical volume along it, was developed by Bachorki et al. (1999). A classical volumetric heat source model is the double ellipsoid distribution that was developed by Goldak, Chakravarti, Bibby (1984). Wahab, Painter, Davies (1998) and $\mathrm{Wu}$ et al. (2009) combined the double ellipsoid with spherical and cylindrical volumes along the thickness, respectively.

The surface Gaussian heat source model is generally used for thin plates, where the distribution along the thickness is not important. Therefore, this study investigates its accuracy in welding processes of plates with different thickness. Analyses are performed by the ANSYS® software, considering the convection and the radiation phenomena. Several cases of different parameters of heat distribution, heat input and plate thickness have had their weld pool geometries analyzed and compared with those obtained experimentally.

\section{2 - THERMAL ANALYSIS}

During the welding process, the thermal field is governed by the heat conduction equation given by:

$$
\begin{aligned}
& \frac{\partial}{\partial x}\left(k(T) \frac{\partial T}{\partial x}\right)+\frac{\partial}{\partial y}\left(k(T) \frac{\partial T}{\partial y}\right)+\frac{\partial}{\partial z}\left(k(T) \frac{\partial T}{\partial z}\right)+Q_{V}= \\
& \rho(T) C_{p}(T) \frac{\partial T}{\partial t}
\end{aligned}
$$

Where $T$ is the temperature, $k(T)$ is the thermal conductivity, $\rho(T)$ is the specific mass, $C_{p}(T)$ is the specific heat and $Q_{V}$ is the volumetric heat flux. The thermodynamic boundary conditions on the external surfaces of the solid comprise heat transfer for convection and radiation.

The heat flow density for convection $\left(q_{c}\right)$ in the environment gas or liquid is given by Newton's heat transfer law:

$$
q_{c}=\rho(T) h_{c}\left(T-T_{0}\right)
$$

Where $T$ is the temperature of the external surface, $T_{0}$ is the temperature of gas or liquid and $h_{c}$ is the coefficient of convective heat transfer. This coefficient depends on the convection conditions on the solid surface, besides the properties of the surface and the environment. Authors, such as Sorensen (1999), Teng et al. (2001) and Gery, Long, Maropoulos (2005), have proposed values of coefficient of convective heat transfer from 15 to 25 $\mathrm{W} / \mathrm{m}^{2} \mathrm{~K}$ (Araújo, 2012).

The heat flow density for radiation $q_{r}$ is governed by the Stefan-Boltzmann law, as follows:

$q_{r}=\varepsilon_{r} \sigma_{r}\left(T^{4}-T_{0}^{4}\right)$

Where $\varepsilon$ is the emissivity of the material surface and $\sigma_{r}$ is the Stefan-Boltzman constant. The value of the emissivity depends on the temperature in the welding process (Paloposki and Liedquist, 2005; Araújo, 2012), in which it ranges from room temperature to approximately $1450{ }^{\circ} \mathrm{C}$. In general, the higher the temperature, the larger the emissivity.

In this study, the heat of the welding arc was modeled by a traveling two-dimensional distribution of heat source with a Gaussian distribution. Therefore, the heat flux distribution on the surface of the solid is related to the radial position $r$ (whose origin is the arc center), as follows (Goldak and Akhlaghi, 2005).

$q(r)=\frac{\eta U I}{2 \pi \sigma^{2}} e^{-\left(r^{2} / 2 \sigma^{2}\right)}$

Where $q(r)$ is the surface flux at radius $r, \eta$ is the efficiency coefficient, $U$ is the voltage, $I$ is the current and $\sigma$ is the radial distance from the center. 


\section{3 - CASE STUDY}

The case consists of bead-on-plate welding which was studied numerically and experimentally. The experiments were carried out at the welding laboratory in the Engineering School at the Universidade Federal do Rio Grande - FURG and consist of bead-on-plate welding on four plate specimens $(200 \mathrm{~mm}$ x $50 \mathrm{~mm})$ with different thickness: $3 \mathrm{~mm}, 4 \mathrm{~mm}, 5 \mathrm{~mm}$ and $6 \mathrm{~mm}$. The material of the plates is the ASTM A36 steel and the welding process is the Tungsten Inert Gas (TIG) with Argon gas in a flow rate of $12 \mathrm{l} / \mathrm{min}$. The distance from the electrode to the plate surface is $3 \mathrm{~mm}$ and the welding speed is $5 \mathrm{~mm} / \mathrm{s}$. The actual weld pool cross section is obtained by cutting the welded plate which is attacked by nital $2 \%$ to carry out the metallographic analysis.

In the numerical simulations, three different heat inputs of $240 \mathrm{~J} / \mathrm{mm}, 320 \mathrm{~J} / \mathrm{mm}$ and $400 \mathrm{~J} / \mathrm{mm}$ were imposed and the dependence on specific heat $\left(C_{p}\right)$ and thermal conductivity $(k)$ with temperature for ASTM A36 steel is implemented, as shown in Figure 1. Since the specific mass $(\rho)$ is almost constant with the temperature, a constant value of $7850 \mathrm{~kg} / \mathrm{m}^{3}$ and heat input efficiency of 0.70 were adopted in this study. An average emissivity of $\varepsilon_{r}=0.8$ is adopted for ASTM A36 steel and the coefficient of convective heat transfer is equal to $h c=20 \mathrm{~W} / \mathrm{m}^{2} \mathrm{~K}$.

Figure 1 - Specific heat $\left(C_{p}\right)$ and thermal condutivity $(k)$ related to temperature $T$ for ASTM A36 steel (Deng and Murakawa,

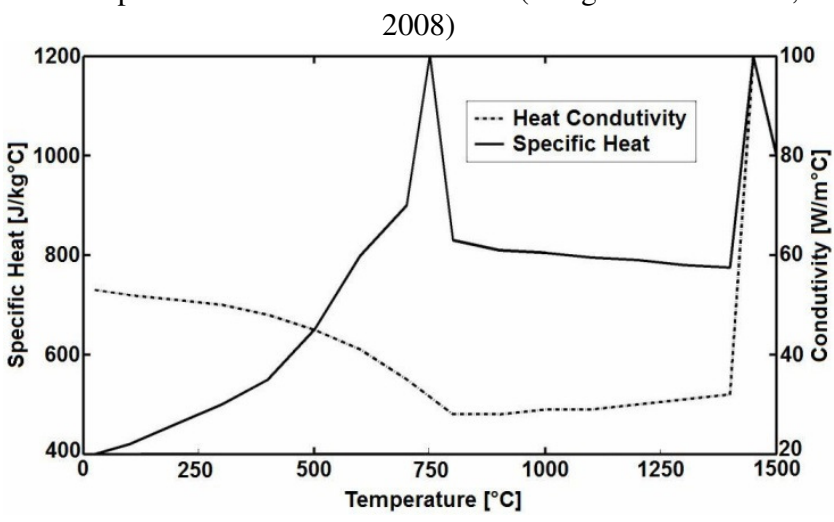

4 - RESULTS

Numerical analyses were carried out by ANSYS $^{\circledR}$, which solves the transient thermal equation (Eq. 1) by using the FEM. Hexahedral elements with eight nodes and surface elements were employed to impose the radiation condition. The mapped mesh had 29749 nodes and 37416 elements, as shown in Figure 2. In the central region up to $0.01 \mathrm{~m}$ from the welding line, to both sides, the element size was $1 \mathrm{~mm}$ while out of this zone, it was $2 \mathrm{~mm}$. The Gaussian heat source moved every $0.2 \mathrm{~s}$ and the radial distances from the center, $\sigma$, were $0.5 \mathrm{~mm}, 1 \mathrm{~mm}, 2 \mathrm{~mm}, 3 \mathrm{~mm}$ and $4 \mathrm{~mm}$. In Figure 3 is showed the Gaussian distribution or each $\sigma$ value. The time step was $0.3 \mathrm{~s}$ and the whole simulation lasted $60 \mathrm{~s}$.

Figure 2 - Finite element mesh for the case study



Figure 3. Gaussian distribution for values of $\sigma$ equal to (a) $0.5 \mathrm{~mm}$, (b) $1 \mathrm{~mm}$, (c) $2 \mathrm{~mm}$, (d) $3 \mathrm{~mm}$, (e) $4 \mathrm{~mm}$ and (f) $5 \mathrm{~mm}$

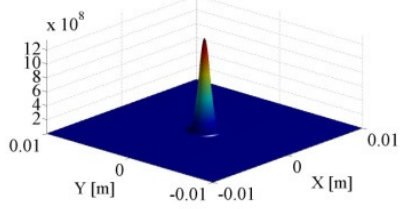

(a)

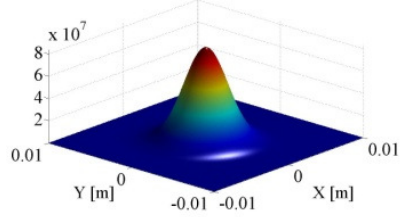

(c)

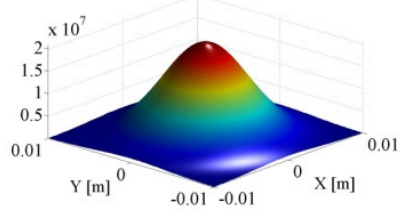

(e)

In Figure 4 is showed the temperature distributions for $3 \mathrm{~mm}$ thick plate at four instants $(10 \mathrm{~s}, 20 \mathrm{~s}, 30 \mathrm{~s}$ and $60 \mathrm{~s})$ during the simulation, in which the heat input was 240 $\mathrm{J} / \mathrm{mm}$ and $\sigma=1 \mathrm{~mm}$. High temperature around the heat source could be observed during the welding process (until $40 \mathrm{~s}$ ). Afterwards, the temperature variation in the plate got smoother (Figure 4d). 
Figure 4 - Temperature distribution at (a) $10 \mathrm{~s}$, (b) $20 \mathrm{~s}$, (c) $30 \mathrm{~s}$ and (d) $60 \mathrm{~s}$ for $3 \mathrm{~mm}$ thick plate. The heat input is $240 \mathrm{~J} / \mathrm{mm}$ and $\sigma=1 \mathrm{~mm}$

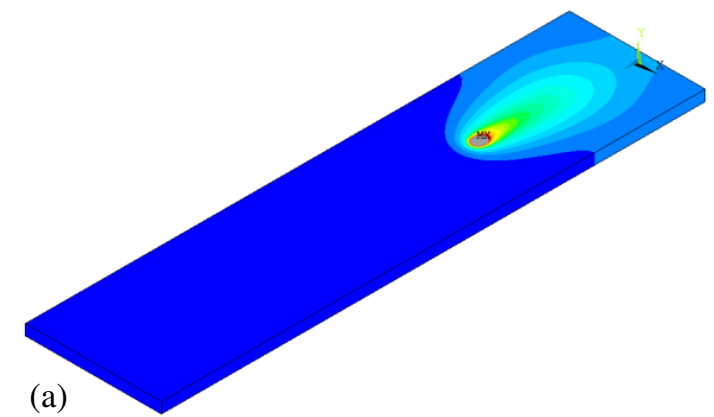

(b)

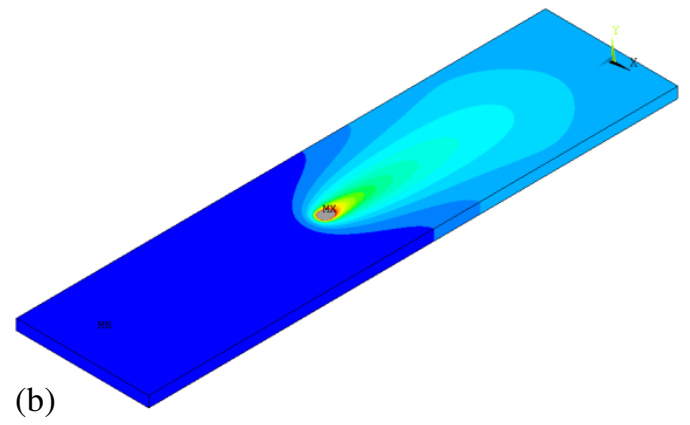

(c)

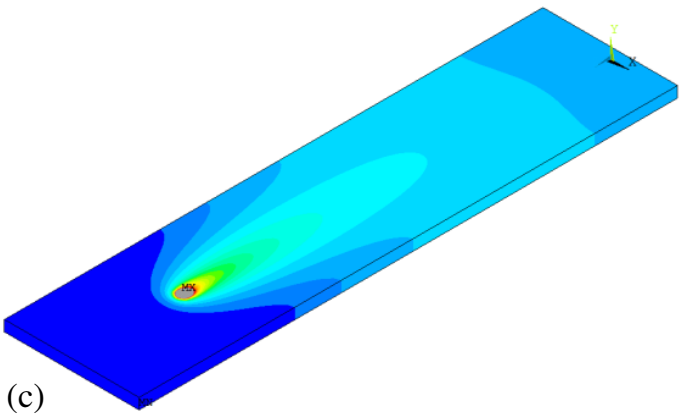

(d)
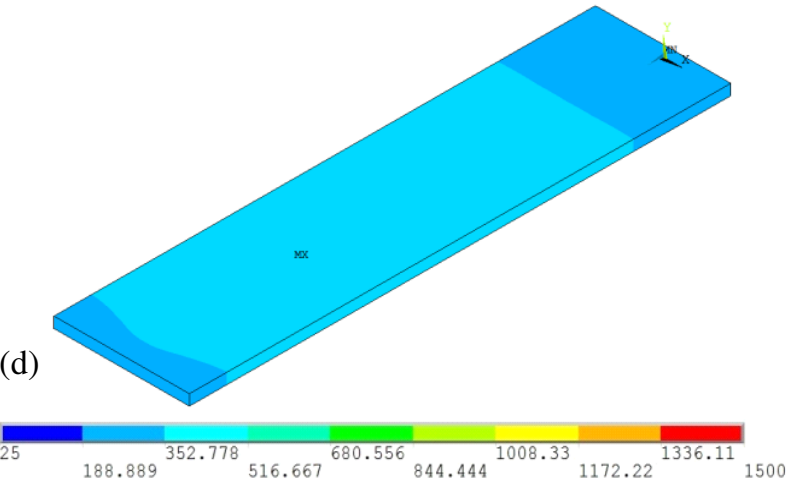

To validate the numerical simulation, the fusion zone shape, numerically obtained on the cross section in the middle of the plate, was compared with experimental results for plate thickness equal to $3 \mathrm{~mm}, 4 \mathrm{~mm}, 5 \mathrm{~mm}$ and $6 \mathrm{~mm}$ and heat input of $240 \mathrm{~J} / \mathrm{mm}$. The bead width and the penetrated depth (Figure 5) of the fusion zone boundary, which was defined by the isothermal line of $1500{ }^{\circ} \mathrm{C}$, were the dimensions used for this comparison. In the numerical simulations, different radial distances of the source heat center, $\sigma$, were tested to choose the one that could get better results by comparison with experimental ones. For these cases, the $\sigma$ value, whose results showed good agreement with experimental ones, was $\sigma=2 \mathrm{~mm}$ for all thickness, which was in accordance with the range (from $1.6 \mathrm{~mm}$ to $4 \mathrm{~mm}$ ) recommended by Eagar and Tsai (1983). The cross sections for plate thickness equal to $3 \mathrm{~mm}, 4$ $\mathrm{mm}, 5 \mathrm{~mm}$ and $6 \mathrm{~mm}$ are shown in Figure 6. In all cases, the boundaries of the fusion zone obtained numerically had similar shapes in comparison with the experimental ones. Therefore, numerical values of the bead width and the penetrated depth had good agreement with those obtained experimentally. This shape (concave curve) was expected because it is typical for TIG process with low power. It is the main reason for good agreement between numerical and experimental results for all plate thicknesses, even in larger ones. These good results enable this methodology to perform the following analyses based on dimension (bead width and penetrated depth) and shape of the weld pool zone boundary.

Figure 5 - Bead width and penetrated depth of the weld pool zone

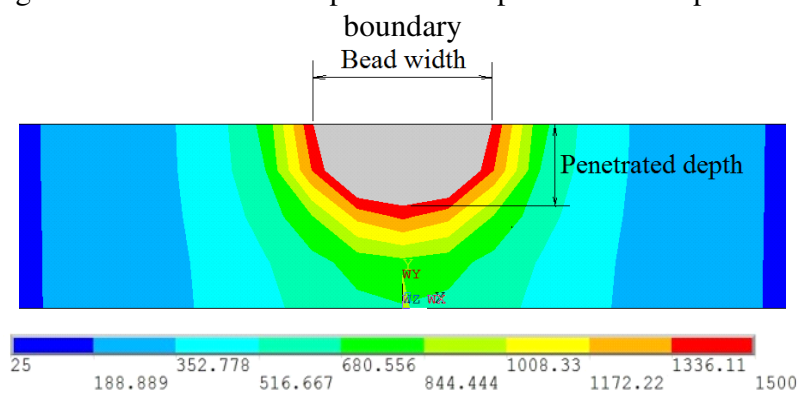

Figure 6 - Fusion zone shape, numerically and experimentally obtained, for plate thickness of (a) $3 \mathrm{~mm}$, (b) $4 \mathrm{~mm}$, (c) $5 \mathrm{~mm}$ and (d) $6 \mathrm{~mm}$

(a)

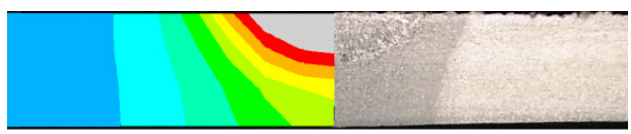

(b)

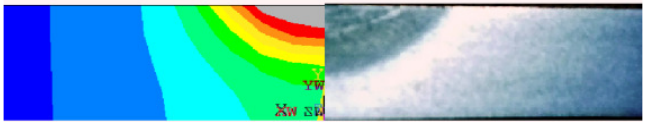

(c)

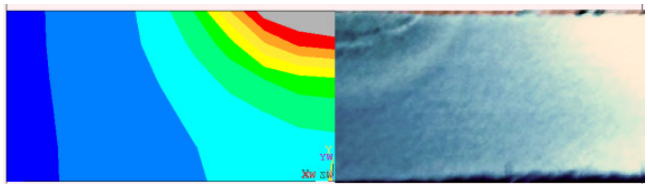

(d)
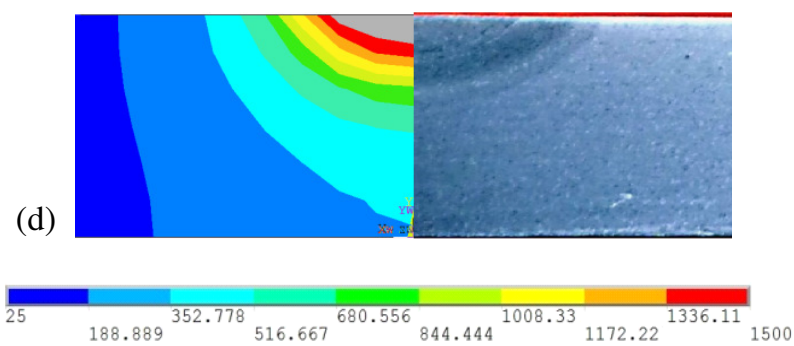
Another analysis evaluated the influence of the welding power and the radial distance of the source heat center, $\sigma$, on the bead width and the penetrated depth of the fusion zone boundary for the $3 \mathrm{~mm}$ thick plate.

In Table 1 is showed the bead width and the penetrated width for different values of $\sigma$ and the heat input obtained by the numerical simulations. In Figure 7 is expressed graphically the values showed in Tab. 1. It is worth mentioning that both $\sigma$ and heat input had much influence on the dimensions of the weld pool zone. The higher the $\sigma$ value, the higher the bead width and the lower the penetrated depth, as shown for different heat input in Figure 7. This behavior was expected because the increase in $\sigma$ values spreads the energy imposed by the source in a larger area, thus increasing the bead width and diminishing the capacity of heat penetration. Different behavior was observed for lower heat input and higher $\sigma$ values, in which the increase in $\sigma$ induced the decrease of bead width and penetrated depth. This phenomenon occurs in $240 \mathrm{~J} / \mathrm{mm}$ and $320 \mathrm{~J} / \mathrm{mm}$ heat input cases, for $\sigma$ higher or equal to $3 \mathrm{~mm}$. In these cases, the heat density in zones far from the center of the heat source is not enough to cause material fusion. Figure 8 shows temperature distribution on the cross section in the middle of the plate for different values of $\sigma$ and heat input equal to $240 \mathrm{~J} / \mathrm{mm}$.

Regarding the influence of heat input on the fusion zone, its growth increased the penetration of the weld up to the point that it reached full penetration (FULL). For the lowest heat input $(240 \mathrm{~J} / \mathrm{mm})$ and highest value of $\sigma$ (4 mm), no melting (NM) occurred, indicating that this combination was inadequately applied.

Table 1 - Bead width (BW) and penetrated depth (PD) for different values of $\sigma$ and heat input

\begin{tabular}{ccccccc}
\hline $\begin{array}{c}\text { Heat Input } \\
(\mathrm{J} / \mathrm{mm})\end{array}$ & \multicolumn{2}{c}{240} & \multicolumn{2}{c}{320} & \multicolumn{2}{c}{400} \\
\hline$\sigma(\mathrm{mm})$ & $\begin{array}{c}\text { BW } \\
(\mathrm{mm})\end{array}$ & $\begin{array}{c}\text { PD } \\
(\mathrm{mm})\end{array}$ & $\begin{array}{c}\text { BW } \\
(\mathrm{mm})\end{array}$ & $\begin{array}{c}\text { PD } \\
(\mathrm{mm})\end{array}$ & $\begin{array}{c}\text { BW } \\
(\mathrm{mm})\end{array}$ & $\begin{array}{c}\text { PD } \\
(\mathrm{mm})\end{array}$ \\
\hline 0.5 & 3.95 & 2.02 & 4.74 & FULL & 5.74 & FULL \\
\hline 1 & 4.59 & 1.80 & 5.47 & FULL & 6.33 & FULL \\
\hline 2 & 4.89 & 1.06 & 6.39 & 1.81 & 7.44 & FULL \\
\hline 3 & 4.20 & 0.33 & 6.33 & 1.04 & 7.98 & 1.95 \\
\hline 4 & $\mathrm{NM}$ & NM & 6.01 & 0.58 & 8.08 & 1.36 \\
\hline
\end{tabular}

Figure 7 - Bead width versus $\sigma$ for $3 \mathrm{~mm}$ thick plate and heat input (Hi) equal to $240 \mathrm{~J} / \mathrm{mm}, 320 \mathrm{~J} / \mathrm{mm}$ and $400 \mathrm{~J} / \mathrm{mm}$

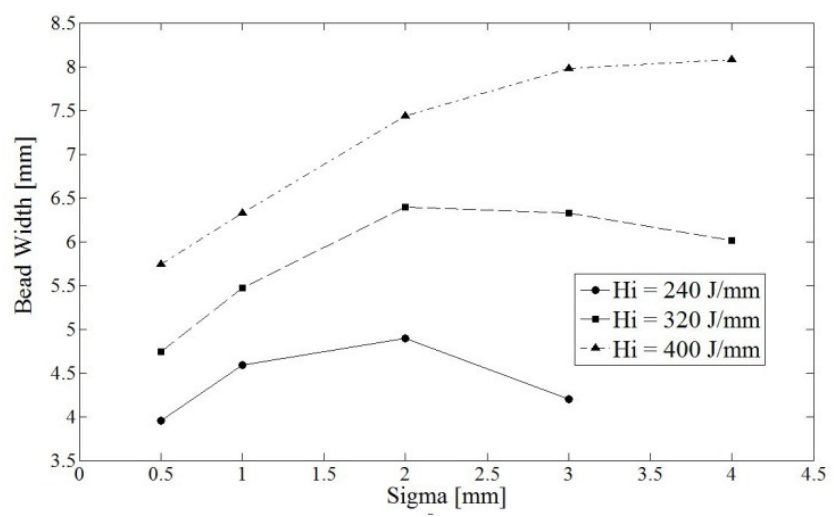

Figure 8 - Temperature distribution at the cross section in middle of the plate for heat input equal to $240 \mathrm{~J} / \mathrm{mm}, 3 \mathrm{~mm}$ thick plate and $\sigma$ equal to (a) $0.5 \mathrm{~mm}$, (b) $1 \mathrm{~mm}$, (c) $2 \mathrm{~mm}$, (d) $3 \mathrm{~mm}$ and (e) $4 \mathrm{~mm}$

(a)

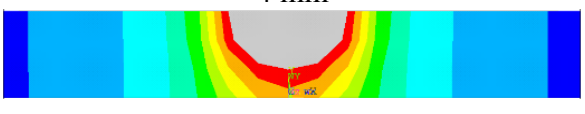

(b)

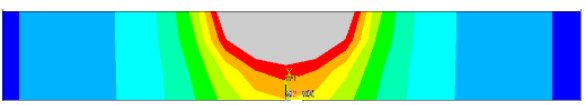

(c)

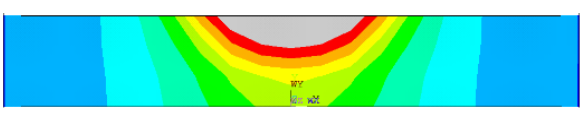

(d)

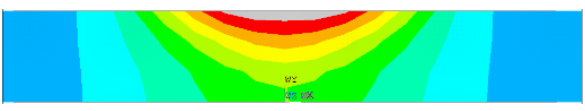

(e)

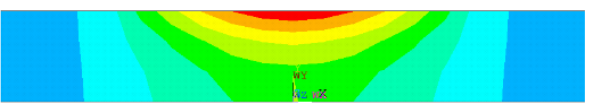

The $\sigma$ value influences the density distribution of the heat source and, consequently, the temperature and the cooling rate distributions, responsible for the phase transformation of the material. The analysis of this aspect is shown in Figures 9 to 11: the temperature along the time for each $\sigma$ at three points on the superior surface of the plate, at the center of the welding bead (Figure 9), and $4 \mathrm{~mm}$ (Figure 10) and $8 \mathrm{~mm}$ (Figure 11) from the center. At the center of the welding bead, as $\sigma$ increases, the maximum temperature decreased significantly. The opposite occurred at $4 \mathrm{~mm}$ and $8 \mathrm{~mm}$ from the center of the welding bead, where the maximum temperature increased with $\sigma$. However, at the three points under analysis, the cooling rates (slope of the curves) were very similar for different $\sigma$ values.

Figure 9 - Temperature along time at the center of the welding bead for different $\sigma$ values

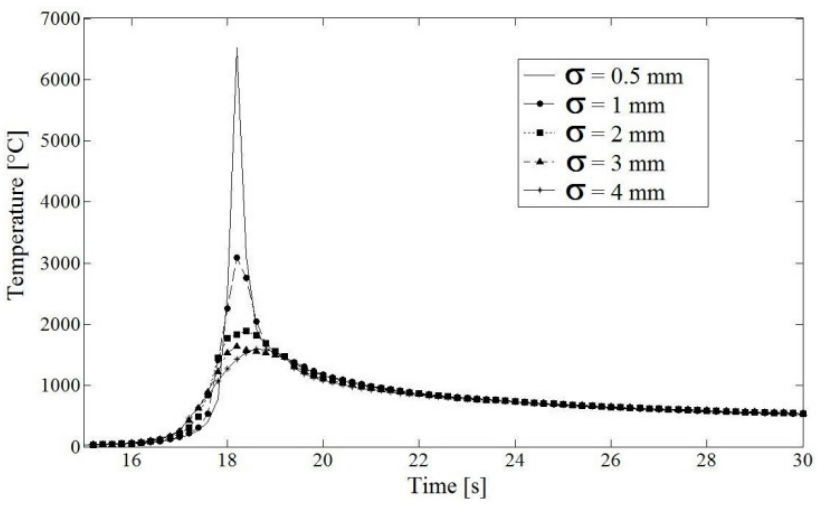


Figure 10 - Temperature along time at $4 \mathrm{~mm}$ from the center of the welding bead for different $\sigma$ values

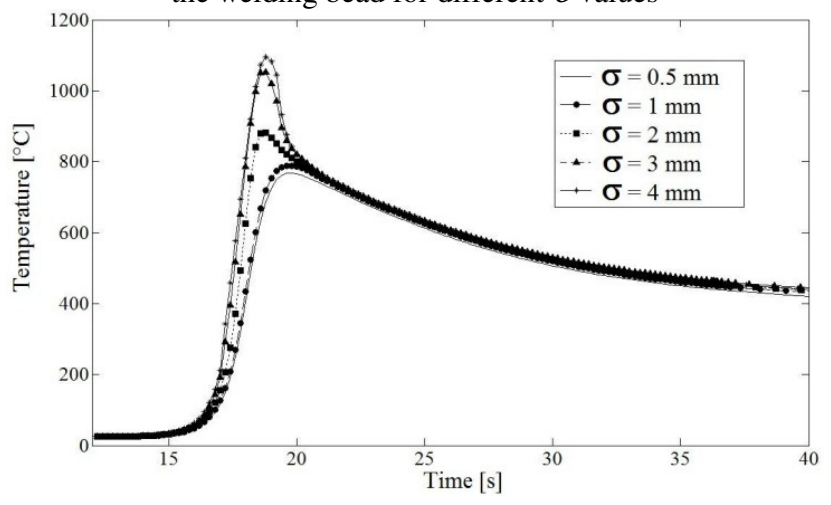

Figure 11 - Temperature along time at $8 \mathrm{~mm}$ from the center of the welding bead for different $\sigma$ values

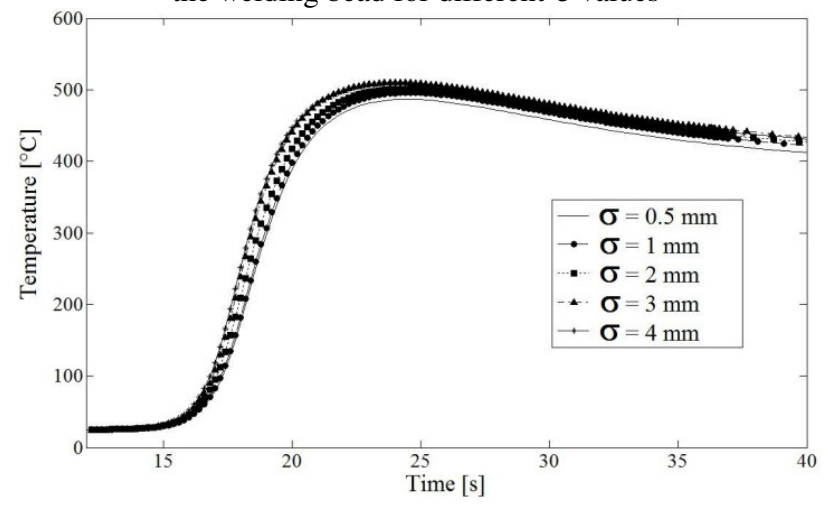

The third analysis evaluated the influence of the thickness of the plate on the penetrated depth and the bead width for different values of welding power. The parameter of the heat source was $\sigma=0.5 \mathrm{~mm}$, the heat input values were $240 \mathrm{~J} / \mathrm{mm}, 320 \mathrm{~J} / \mathrm{mm}$ and $400 \mathrm{~J} / \mathrm{mm}$, and the thicknesses were $3 \mathrm{~mm}, 4 \mathrm{~mm}, 5 \mathrm{~mm}$ and $6 \mathrm{~mm}$. The results are shown in Tab. 2 and the bead width related to the thickness for the three heat input values are shown in Figure 12.

In general, as the thickness increased, the bead width and the penetrated depth decreased, because of the increase of the heat dissipation. Another point of view is related to the behavior of the heat flow that can be considered essentially two-dimensional (2D) or three-dimensional (3D), depending on the welding conditions (Sorensen, 1999). For higher welding powers and thinner plates, the heat flow was predominantly $2 \mathrm{D}$, whereas for lower welding powers and thicker plates, the heat flow was 3D. Therefore, there was a transition thickness in which the heat flow has an intermediate behavior, between 2D (for thickness below the transient one) and 3D (for thickness above the transient one). Since the cooling rate was higher in $3 \mathrm{D}$ heat flow, it was expected that, in the transition region, as the thickness increases, the bead width decreases with more intensity, because the heat flow behavior changes from 2D to 3D. As shown in Figure 12, the bead width had this high variation at thickness between $3 . \mathrm{mm}$ and $4 . \mathrm{mm}$ for $400 \mathrm{~J} / \mathrm{mm}$. The same behavior did not occur for lower heat inputs $(240 \mathrm{~J} / \mathrm{mm}$ and $320 \mathrm{~J} / \mathrm{mm})$, possibly because the heat flow was predominantly 3D for all thickness.

Table 2 - Bead width (BW) and penetrated depth (PD) for different values of heat input and thickness of the plate

\begin{tabular}{ccccccc}
\hline $\begin{array}{c}\text { Heat Input } \\
(\mathrm{J} / \mathrm{mm})\end{array}$ & \multicolumn{2}{c}{240} & \multicolumn{2}{c}{320} & \multicolumn{2}{c}{400} \\
\hline $\begin{array}{c}\text { Thickness } \\
(\mathrm{mm})\end{array}$ & $\begin{array}{c}\text { BW } \\
(\mathrm{mm})\end{array}$ & $\begin{array}{c}\text { PD } \\
(\mathrm{mm})\end{array}$ & $\begin{array}{c}\text { BW } \\
(\mathrm{mm})\end{array}$ & $\begin{array}{c}\text { PD } \\
(\mathrm{mm})\end{array}$ & $\begin{array}{c}\text { BW } \\
(\mathrm{mm})\end{array}$ & $\begin{array}{c}\text { PD } \\
(\mathrm{mm})\end{array}$ \\
\hline 3 & 3.95 & 2.02 & 4.74 & FULL & 5.74 & FULL \\
\hline 4 & 3.87 & 1.76 & 4.50 & 2.24 & 5.09 & 2.66 \\
\hline 5 & 3.81 & 1.64 & 4.34 & 2.16 & 4.94 & 2.44 \\
\hline 6 & 3.74 & 1.63 & 4.32 & 2.11 & 4.92 & 2.35 \\
\hline
\end{tabular}

Figure 12 - Relation between the bead width and the thickness of the plate for heat input (Hi) of $240 \mathrm{~J} / \mathrm{mm}, 320 \mathrm{~J} / \mathrm{mm}$ and 400

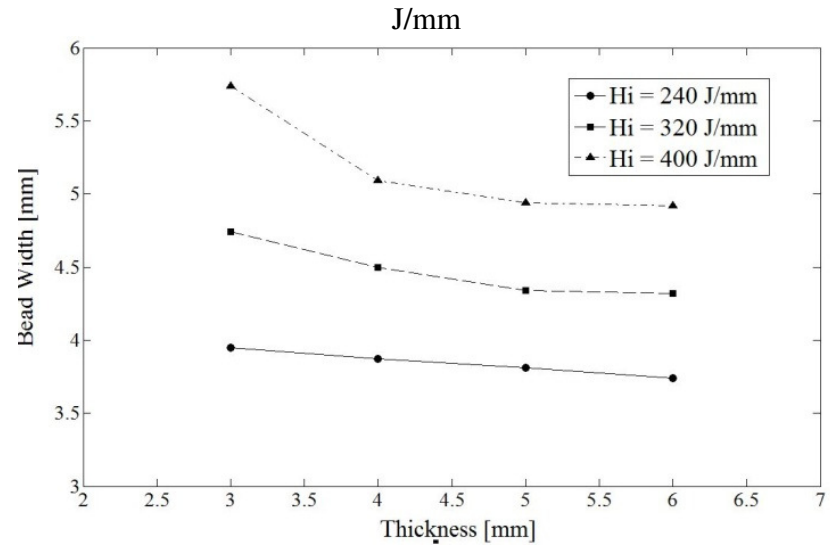

CONCLUSIONS

In this study, the accuracy of the Gaussian heat source model was investigated in bead-on-plate welding by the TIG process. Analyses were performed by the ANSYS ${ }^{\circledR}$ software, considering the convection and the radiation phenomena.

Firstly, the validation of the numerical simulation was carried out comparing the fusion zone shape with that obtained experimentally for plate thickness equal to $3 \mathrm{~mm}$, $4 \mathrm{~mm}, 5 \mathrm{~mm}$ and $6 \mathrm{~mm}$ and heat input of $240 \mathrm{~J} / \mathrm{mm}$. For all cases, the boundaries of the fusion zone obtained numerically had similar shapes by comparison with the experimental ones. It is important to emphasize that this good agreement was reached in these particular conditions; another type of welding process could have produced different boundary shape from the one yielded by the $2 \mathrm{D}$ Gaussian heat source.

The analysis of the influence of the welding power and the radial distance of the source heat center, $\sigma$, on the bead width and the penetrated depth of the fusion zone boundary was performed. The increase of $\sigma$ diminished the heat density and, consequently, increased the bead width and decreased the penetrated depth, except for higher $\sigma$ values, whose increase in $\sigma$ induced the decrease in the bead width and penetrated depth. Although the $\sigma$ value influenced the maximum temperature at the center of the welding bead (as $\sigma$ increased, the maximum temperature decreased), the cooling rate was very similar for different $\sigma$ values. 
The analysis of the influence of the thickness of the plate on the penetrated depth and the bead width for different values of heat input was also carried out. It can be concluded that, as the thickness increases, the bead width and the penetrated depth decrease, because of the increase in the heat dissipation. This phenomenon is also influenced by the behavior of the heat flow (2D or $3 \mathrm{D}$ ), depending on the welding conditions. In this study, for $400 \mathrm{~J} / \mathrm{mm}$ of heat input, the bead width had high variation at thickness between $3 \mathrm{~mm}$ and $4 \mathrm{~mm}$ because the heat flow behavior changed from $2 \mathrm{D}$ to $3 \mathrm{D}$.

This paper showed that the methodology based on the finite element technique and the Gaussian heat source model is a good proposal for bead-on-plate cases when welding TIG processes are employed. Future researches must be developed to investigate the applicability of this model to other welding conditions.

\section{ACKNOWLEDGEMENTS}

The authors acknowledge the support of FAPERGS (project 11/2046-8).

\section{REFERENCES}

ARAÚJO, D. B. Estudo de distorções em soldagem com uso de técnicas numéricas e de otimização. 2012. Ph.D. thesis - Universidade Federal de Uberlândia, Uberlândia, 2012. [in portuguese].

BACHORKI, A.; PAINTER, M. J.; SMAILES, A. J.; WAHAB, M. A. Finite-element prediction of distortion during gas metal arc welding using the shrinkage volume approach. Journal of Materials Processing Technology, v. 92-93, p. 405-409, 1999.

http://dx.doi.org/10.1016/S0924-0136(99)00161-2.

BALASUBRAMANIAN, K. R.; SIVA SHANMUGAM, N.; BUVANASHEKARAN, G.; SANKARANAYANASAMY, K. Numerical and experimental investigation of laser beam welding of AISI304 stainless steel sheet. Advances in Production Engineering \& Management, v. 3 (2), p. 93-105, 2008. BRICKSTAD, B.; JOSEFSON, B. L. A parametric study of residual stresses in multi-pass butt-welded stainless steel pipes. International Journal of Pressure Vessels and Piping, v. 75, p. 11-25, 1998.

http://dx.doi.org/10.1016/S0308-0161(97)00117-8.

CHO, S. H.; KIM, J. W. Analysis of residual stress in carbon steel weldment incorporating phase transformations. Science and Technology of Welding and Joining, v. 7 (4), p. 212-216, 2002.

http://dx.doi.org/10.1179/136217102225004257.

CORET, M.; COMBESCURE, A. A mesomodel for the numerical simulation of the multiphasic behavior of materials under anisothermal loading (application to two low-carbon steels). International Journal of Mechanical Sciences, v. 44, p. 1947-1963, 2002.

http://dx.doi.org/10.1016/S0020-7403(02)00053-X.

DENG, D.; MURAKAWA, H. Prediction of welding distortion and residual stress in a thin plate butt-welded joint. Computational Materials Science, v. 43, p. 353365, 2008.

http://dx.doi.org/10.1016/j.commatsci.2008.01.003. http://dx.doi.org/10.1016/j.commatsci.2007.12.006.

DENG, D.; MURAKAWA, H.; LIANG, W. Numerical simulation of welding distortion in large structures. Computer Methods in Applied Mechanics and Engineering, v. 196 (45-48), p. 4613-4627, 2007. http://dx.doi.org/10.1016/j.cma.2007.05.023.

DONG, P. The mechanics of residual stress distributions in girth welds. In: Procedures of the second international conference on integrity of high temperature welds, London, 2003.

EAGAR, T. W.; TSAI, N. S. Temperature fields produced by traveling distributed heat sources. Welding Journal, v. 62 (12), p. 346-355, 1983.

EL-AHMAR, W. Robustesse de la simulation numérique du soudage TIG de structures 3D en acier 316L. 2007. Ph.D. thesis - Institut National des Sciences Appliquées de Lyon, Lyon, 2007.

FANOUS, I. F.; YOUNAN, M. Y; WIFI, A. S. 3D finite element modeling of the welding process using element birth and element movement techniques. Pressure Vessels and Piping Division, v. 442, p. 165-172, 2002.

FREE, J.A.; GOLF, R.F.D.P. Predicting residual stresses in multi-pass weldments with the finite element method. Computers and Structures, v. 32 (2), p. 365-378, 1989. http://dx.doi.org/10.1016/0045-7949(89)90048-5.

FRIEDMAN, E. Thermomechanical analysis of the welding process using the finite element method. Journal of Pressure Vessel Technology, v. 97, p. 206-213, 1975. http://dx.doi.org/10.1115/1.3454296.

GERY, D.; LONG, H.; MAROPOULOS, P. Effects of welding speed, energy input and heat source distribution on temperature variations in butt joint welding. Journal of Materials Processing Technology, v. 167 (2-3), p. 393401, 2005.

http://dx.doi.org/10.1016/j.jmatprotec.2005.06.018.

GOLDAK, J. A.; AKHLAGHI, M. Computational Welding Mechanics. New York: Springer, 2005.

GOLDAK, J. A.; CHAKRAVARTI, A.; BIBBY, M. A new finite element model for welding heat sources. Metallurgical Transactions, v. 15, p. 299-305, 1984. http://dx.doi.org/10.1007/BF02667333.

JOSEFSON, B. L. Prediction of residual stresses and distortions in welded structures. ASME Journal of Offshore Mechanics and Arctic Engineering, v. 115, p. 52-57, 1993. http://dx.doi.org/10.1115/1.2920089.

LINDGREN, L. E. Modelling for residual stresses and deformations due to welding-knowing what is not necessary to know. Mathematical Modelling of Weld Phenomena, v. 6, p. 491-518, 2001.

MOCHIZUKI, M.; MATSUSHIMA, S.; TOYODA, M.; THAULOW, C. Fundamental study of thermal stress generation during welding heat cycles. Studies on numerical simulation of temperature, microstructure and thermal stress histories during welding and their application to welded structures. Welding International, v. 19 (9), p. 702-710, 2005.

http://dx.doi.org/10.1533/wint.2005.3490. 
MURAKI, T.; BRYAN, J. J.; MASUBUCHI, K. Analysis of thermal stresses and metal movement during welding. ASME Journal of Engineering Materials and Technology, v. 96, p. 81-84, 1975.

http://dx.doi.org/10.1115/1.3443265.

PALOPOSKI, T.; LIEDQUIST, L. Steel emissivity at high temperatures. VTT Tiedotteita, Research Notes 2299, Otamedia Oy, Espoo, Finland, 2005.

PAPAZOGLOU, V. J.; MASUBUCHI, K. Numerical analysis of thermal stresses during welding including phase transformation effects. Journal of Pressure Vessel Technology, v. 104, p. 198-203, 1982.

http://dx.doi.org/10.1115/1.3264204.

RAYAMYAKI, P.; KARKHIN, V. A.; KHOMICH, P. N. Determination of the main characteristics of the temperature field for the evaluation of the type of solidification of weld metal in fusion welding. Welding International, v. 8, p. 600-604, 2007.

ROSENTHAL, D. Mathematical theory of heat distribution during welding and cutting. Welding Journal, v. 20 (5), p. 220s-234s, 1941.

SORENSEN, M. B. Simulation of welding distortion in ship section. Ph.D. thesis - University of Denmark, Lyngby, Denmark, 1999.

TENG, T. L.; FUNG, C. P.; CHANG, P. H.; YANG, W. C. Analysis of residual stresses and distortions in $\mathrm{T}$-joint fillet welds. International Journal of Pressure Vessels and Piping, v. 78, p. 523-538, 2001.

http://dx.doi.org/10.1016/S0308-0161(01)00074-6.

ZAEH, M. F.; SCHOBER, A. Approach for modelling process effects during friction stir welding of composite extruded profiles. Advanced Materials Research, v. 43, p. 105-110, 2008.

http://dx.doi.org/10.4028/www.scientific.net/AMR.43.105. ZIOLKOWSKI, M.; BRAUER, H. Modeling of Seebeck effect in eletron beam deeep welding of dissimilar metals. The International Journal for Computation and Mathematic in Electric and Electronic Engineering, v. 28, p. 140-153, 2009.

http://dx.doi.org/10.1108/03321640910918940.

WAHAB, M. A.; PAINTER, M. J.; DAVIES, M. H. The prediction of the temperature distribution and weld pool geometry in the gas metal arc welding process. Journal of Materials Processing Technology, v. 77, p. 233-239, 1998. http://dx.doi.org/10.1016/S0924-0136(97)00422-6.

WU, C. S.; HU, Q. X.; GAO, J. Q. An adaptive heat source model for finite-element analysis of key hole plasma arc welding. Computational Material Science, v. 46, p. $167-$ 172, 2009.

http://dx.doi.org/10.1016/j.commatsci.2009.02.018. 